\title{
TODO LO QUE NO SE VIO
}

https://doi.org/10.22201/fesa.figuras.2021.3.1.200

\section{David Huerta}

No se vio el horizonte, no se vio tampoco la punta de la montaña; no se vio el mar ni se vio el bosque y ninguna de las hojas se vio. No se vio al padre ni a la madre, no se vio a los hijos ni a los sobrinos, no se vio el cráter ni el nardo ni la gusanera ni el friso sublime. No se vio el desierto ni la nieve de los polos ni la provincia llamada No Se Sabe Dónde, ni el reino de Nunca Jamás ni el momento llamado ayer ni el minuto baldío en la carátula del reloj, un reloj que tampoco se vio. Los ojos cerrados no pudieron ver ni tampoco pudieron ver los ojos abiertos. El Aleph se ocultó y quedó envuelto en invisibilidad y la oscuridad se ocultó en la luz y no se vio y la luz se dobló sobre sí misma y el color gris aparentó esconderse en el color azul y este a su vez en el color blanco y los numerosos cuadros del Palacio de Invierno se juntaron en un remolino como dice Osip Mandelstam y ese remolino giró en un vértigo nunca atestiguado por nadie y dio como resultado una imagen que al final tampoco pudo verse, un amasijo de abismo, dolores y exaltaciones y música verbal y trasmundo: la Divina Comedia. 